\title{
The Detection of Brucella Bacteria with PCR and Bacteriological Method in Raw Milk and Some of the Dairy Products Which Are Consumed in Kars*
}

\author{
GUVEN GULBAZ1, UFUK KAMBER ${ }^{2}$ \\ ${ }^{1}$ Food Engineering Department, Engineering - Architecture Faculty, Kafkas University, Kars/Turkey \\ ${ }^{2}$ Food Hygiene and Technology Department, Veterinary Faculty, Kafkas University, Kars/Turkey \\ *Corresponding author: gulbaz68@hotmail.com \\ Bulletin UASVM Veterinary Medicine 73(1) / 2016, \\ Print ISSN 1843-5270; Electronic ISSN 1843-5378 \\ DOI:10.15835/buasvmcn-vm: 11820
}

\begin{abstract}
Because of the abort by the contamination to the humans via direct contact with infected animals or the consumption of contaminated raw milk and dairy products, brucellosis greatly causes to economic loss. For this reason, the annihilating of the effect of this disease is considerably important. Here, we aimed to detect the existence of Brucella bacteria in raw milk, cheese which is produced from raw milk and butter samples by using isolation, identification and PCR molecular techniques. Brucella type agents were detected in within a year by using 315 samples; 215 raw milk, 50 cheeses, 50 butter. Cheese and butter samples were obtained from raw milk. The grams coloring, oxidase, catalase, urease and $\mathrm{H}_{2} \mathrm{~S}$ analysis of 215 raw milk samples showed that only 4 (1.86\%) samples was Brucella positive. As a result, we have determined that there are several types of Brucellosis bacteria in milk, cheese and butter samples. Milk and dairy products can create a risk in Kars because of brucellosis.
\end{abstract}

Keywords: Brucella spp, butter, cheese, PCR, raw milk

\section{INTRODUCTION}

Brucellosis is commonly known as a threat to public health because of the consumption of milk and dairy products that are produced in traditional ways in Turkey and many other countries in the world (Corbel, 1997; Pappas et al., 2006; Akpınar, 2016). Human brucellosis remains a prevalent zoonotic disease around the world with more than 500.000 new cases reported each year (Atluri et al., 2011). Brucellosis is a major zoonosis that is transmitted either by direct contact with animals or their secretions, or by consuming contaminated milk and dairy products (Aparicio, 2013, Corbel, 1997; Renukaradhya et al., 2002).

Brucellosis (also known as 'Mediterranean fever', 'fluctuating fever' 'Malta Fever' and 'Bang Disease') presents as an infectious, contagious, acute, sub-acute or chronic disease created by microorganisms and it is common throughout the world. This disease causes significant yield losses in animal production, making it a significant concern for human, domestic and wild animal diseases (Corbel, 1997; Garcell et al., 2016; Leong et al., 2016). The infection is caused by B.abortus in cattle, B.melitensis or B.ovis in goats and sheep, and these bacteria have been found in many animal species including sea mammals (Leal-Klevezas et al.,1995; Aparicio, 2013).

Brucellosis poses a major public health risk because human brucellosis is still a significant public health problem in Turkey (Yumuk and O'Callaghan, 2012). Scientists have made contributions to the overall picture of Brucellosis in Turkey with local studies (Çetinkaya et al., 2005; Arasoğlu et al., 2013; Çelebi et al., 2013; Kara and Akkaya, 2013). As it is well known that the Brucellosis generally appears in developing countries, several studies have been conducted 
to investigate Brucellosis rates in those countries (Karagiannis et al., 2012; Mailles et al., 2012; Havas et al., 2014; Shehu, 2014; Wareth et al., 2014; Mugizi et al., 2015; Rock et al., 2016). In Turkey, a study conducted by Iyisan et al., (2000) found that the rate was $3.56 \%$ in cattle and $1.26 \%$ in goats in 1989 , and that this percentage was $1.2 \%$ in cattle, $2.08 \%$ in goats in 1990 , and that it was $1.01 \%$ in cattle, $1.83 \%$ in sheep and goats in 1991. Kaynak et al., (2016) published a study reporting that they found Brucella spp. in 2\% of raw milk samples.

In a study done by Charisis (1998) in Mediterranean countries, it was emphasized that the scale of human brucellosis cannot be determined and that there has been a significant increase in human cases in Turkey, from $3.03 / 100.000$ in 1986 to $15.11 / 100.000$ in 1996 . This increase was probably seen as a result of improved observation and diagnosis techniques, more accurate results and better record keeping. Because cases of Brucella infection in animals can last as long as the animal's life, it is common to observe continuous infection of mammary glands and lymph nodes of the mammary gland. In light of this, it has been reported that the Brucella agents are excreted in the milk during the ongoing lactation period. For this reason, it is recommended that the cows be isolated from the milk production process (Ataş et al., 2007).

Although cultures and serologic tests are widely used to identify Brucella agents in tissue, waste, blood and food, the PCR technique has also become more prevalent in recent years (Gupta et al., 2006; Ali et al., 2014; Wareth et al., 2014; Qasem et al., 2015; Kaynak et al., 2016). The polymerase chain reaction (PCR) technique is a rapid and sensitive method (Hamdy and Amin, 2002) used to determine the genus of Brucellosis and other pathogenic bacteria (E. coli) (Herman and Ridder, 1992; Allmann et al., 1995; Rudi et al., 2002). This technique can be used with specific enzymes to identify a specific genus (Tantillo et al., 2001; Funk et al., 2005). In addition, the PCR technique is useful for detecting Brucellosis not only in bovine milk and its products but also in ovine milk and its products.

\section{MATERIALS AND METHODS}

Our aim was to use isolation, identification and PCR molecular techniques to investigate Brucella agents in samples of raw milk and in cheese and butter produced from raw milk sold in Kars province. This study employed traditional analysis to determine that $1.86 \%$ of the raw milk samples contained the brucellosis agent, and these results were supported with PCR measurements, which is a molecular technique.

\section{Milk samples}

The samples used in the analysis were taken from markets, dairy farms and grocery stores which sell these products in sterilized bags under aseptic circumstances. Approximately $100 \mathrm{ml} /$ gr amounts of the samples were brought to the laboratory at Kafkas University in the Faculty of Veterinary Food Hygiene and Technology, and they were immediately analyzed without waiting. The existence of the Brucella type bacteria were investigated over one year and evaluated 315 samples: 215 of cow milk, 50 of cheese and 50 of butter.

\section{Microbiological analysis}

In this study, $10 \mathrm{ml}$ milk, $10 \mathrm{gr}$ cheese and 10 gr butter samples were homogenized for 2-3 minutes in a stomacher, by putting them in a bag which contained $90 \mathrm{ml}$ Brucella Broth. After that, we took $1 \mathrm{ml}$ from each sample and put them to the different two tubes which contained $9 \mathrm{ml}$ Brucella Broth, at next stage the samples were vortexed. One of the tubes was incubated in aerobic environment and the other tube was incubated in an atmosphere of $10 \% \mathrm{CO}_{2}$ at $37 \pm$ $2^{\circ} \mathrm{C}$ for 5-7 days. At the end of this 5-7 day period, a tube which contained Brucella Agar was cultivated twice by the streaking method. One of them was incubated in a $37^{\circ} \mathrm{C}$ incubator and the other in 37 ${ }^{\circ} \mathrm{C}$ incubator in $10 \% \mathrm{CO}_{2}$. Gram coloring, oxidase, catalase, urease and $\mathrm{H}_{2} \mathrm{~S}$ tests were applied to the samples that exhibited reproduction (Farrell and Robertson, 1972).

\section{PCR analysis}

Extraction of genomic DNA from the samples: The protocol that was developed for DNA extraction was carried out as follows: The PCR process was applied to Brucella-positive samples. For the PCR process, the DNA was obtained by using a DNA extraction kit (FERMENTASE). Samples were taken from colonies in Brucella agar, placed in $1.5 \mathrm{ml}$ FTS and centrifuged at $+4{ }^{\circ} \mathrm{C}$ at $5000 \mathrm{~g}$ for $10 \mathrm{~min}$. After the supernatant on top of the pellet was poured off, $180 \mu$ digestion solution and $20 \mu$ proteinase $\mathrm{K}$ were added, and then it was incubated at $56^{\circ} \mathrm{C}$ for 30 minutes. Afterward, $200 \mu \mathrm{l}$ lysis and $400 \mu \mathrm{l}$ 
$50 \%$ ethanol were added to the samples. Lysate GeneJet was prepared and centrifuged at $6000 \mathrm{~g}$ for $1 \mathrm{~min}$. The upper portion was removed, 500 $\mu \mathrm{l}$ ethanol washing solution I was added and then it was centrifuged at $8000 \mathrm{~g}$ for $1 \mathrm{~min}$. The upper portion was removed again, $500 \mu$ l ethanol washing solution II was added and then it was centrifuged at a minimum of $12000 \mathrm{~g}$ for $3 \mathrm{~min}$. $200 \mu$ l Elution buffer was added to the resulting pellet, which was held at room temperature for 2 min. and then centrifuged at $8000 \mathrm{~g}$ for $1 \mathrm{~min}$. The resulting DNA pellet was stored at $-20{ }^{\circ} \mathrm{C}$ until it was analyzed.

Implementation of PCR protocol: Amplification reaction mixtures were prepared in volumes of 50 $\mu \mathrm{l}$ containing PCR buffer, $1.5 \mathrm{mM} \mathrm{MgCl}, 200 \mu \mathrm{M}$ deoxynucleoside triphosphate, $1 \mu \mathrm{M}$ primer, 200 ng of genomic DNA and 2.5 U of DNA polymerase. The temperature cycling for the amplification was performed in a thermocycler (BIO RAD T100) as follows: the first cycle was $94 \stackrel{\circ}{\circ} \mathrm{C}$ for $2 \mathrm{~min}$ and the next 40 cycles were $94^{\circ} \mathrm{C}$ for $2 \mathrm{~min}$, followed by $58 \stackrel{\circ}{\circ} \mathrm{C}$ for 45 seconds, $72{ }^{\circ} \mathrm{C}$ for 45 seconds and a final cycle of $58{ }^{\circ} \mathrm{C}$ for 45 seconds and $72{ }^{\circ} \mathrm{C}$ for $10 \mathrm{~min} / 1$ cycle. The size of the amplified DNA was determined by electrophoresis on $0.8 \%$ agarose gels and compared with DNA molecular weight standards. A DNA-free control (distilled water) was also used to monitor contamination. The sample was examined in a UV transilluminator emitting light at a wavelength of $312 \mathrm{~nm}$, and the results were recorded in a gel imaging system. Each sample was tested at least twice.

Statistical analysis: Chi-square analysis showed no differences between the bacteriological culture and PCR methods for detecting the $B$. abortus antigen.

\section{RESULTS AND DISCUSSION}

At the end of the laboratory analysis, which included gram coloring, oxidase, catalase, urease and $\mathrm{H}_{2} \mathrm{~S}$ of 215 raw milk samples, it was determined that only $4(1.86 \%)$ samples were Brucella positive.

According to the above data, it was seen that there was reproduction in 17 of the 215 milk samples. In gram coloring done in the colonies which had reproduction, 8 samples were gram positive and 9 samples were gram negative. As a result of the oxidase, catalase and urease experiments that were applied to gram negative samples, only $4(1.86 \%)$ samples were found positive for Brucella. After applying the PCR process on the Brucella positive samples, DNA extraction revealed that these 4 Brucella isolates were $100 \%$ B.abortus.

In our study, our aim was to investigate quickly and accurately the prevalence of Brucella agents in milk and dairy products using the PCR molecular technique. Therefore, this study investigated 215 raw milk samples, 50 cheese samples and 50 butter samples (a total of 315 samples) that were sold in Kars province. B.abortus was identified in 4 of 215 raw milk samples that were analyzed in this study. While this value was found to be lower than those reported in other studies, Zowghi et al. ( 2008 ) found a rate of $25.2 \%$ in raw cow milk, LealKlevezas et al. (1995) found a rate of $64 \%$ in raw goat milk, Turutoglu et al. (2003) found a rate of $3 \%$ in cow milk samples using MRT and a rate of $17.7 \%$ in sheep milk, and Gulluce and Leloglu (1996) found a rate of $56 \%$ using MRT and $65.6 \%$ using ELISA. Our results were similar to the result that Celebi and Otlu (2011) reported, which was 4.4\% at after a serological survey of cow milk samples. Kara and Akkaya (2013) investigated 100 fresh cheese samples produced in Afyonkarahisar and found 2\% B.abortus and 7\% B.melitensis. Romero et al. (1995) conducted a study using ELISA and PCR techniques to detect Brucella antibodies and Brucella DNA, respectively. They performed their study on milk samples from 56 cows and found that milk from 37 of the cows was culture-positive for Brucella. They determined that $87.5 \%$ of the

Tab. 1. Brucellosis isolation results of the studied samples

\begin{tabular}{|c|c|c|c|c|c|c|c|c|c|c|c|c|}
\hline \multirow{2}{*}{$\begin{array}{c}\text { Investigated } \\
\text { Material }\end{array}$} & \multirow{2}{*}{$\begin{array}{c}\text { Number of } \\
\text { Samples }\end{array}$} & \multirow{2}{*}{$\begin{array}{l}\text { Reproduction } \\
\text { Number }\end{array}$} & \multicolumn{2}{|c|}{$\begin{array}{c}\text { Gram } \\
\text { Staining }\end{array}$} & \multicolumn{2}{|c|}{ Oxidase } & \multicolumn{2}{|c|}{ Catalase } & \multicolumn{2}{|c|}{ Urease } & \multicolumn{2}{|c|}{$\mathrm{H}_{2} \mathrm{~S}$} \\
\hline & & & + & - & + & - & + & - & + & - & + & - \\
\hline Milk & 215 & 17 & 8 & 9 & 4 & 5 & 4 & 5 & 4 & 5 & 4 & 5 \\
\hline Cheese & 50 & - & 0 & 0 & 0 & 0 & 0 & 0 & 0 & 0 & 0 & 0 \\
\hline Butter & 50 & - & 0 & 0 & 0 & 0 & 0 & 0 & 0 & 0 & 0 & 0 \\
\hline
\end{tabular}


milk samples were positive for Brucella DNA and and $98.2 \%$ were positive for Brucella antibodies.

With regard to other studies that used PCR, Ali et al. (2014) identified Brucella spp. at a rate of 9.5\% in raw milk in Pakistan, Mugizi et al., (2015) identified it in cow milk at a rate of $5.31 \%$, and Kaynak et al. (2016) identified it in raw milk at a rate of $2 \%$.

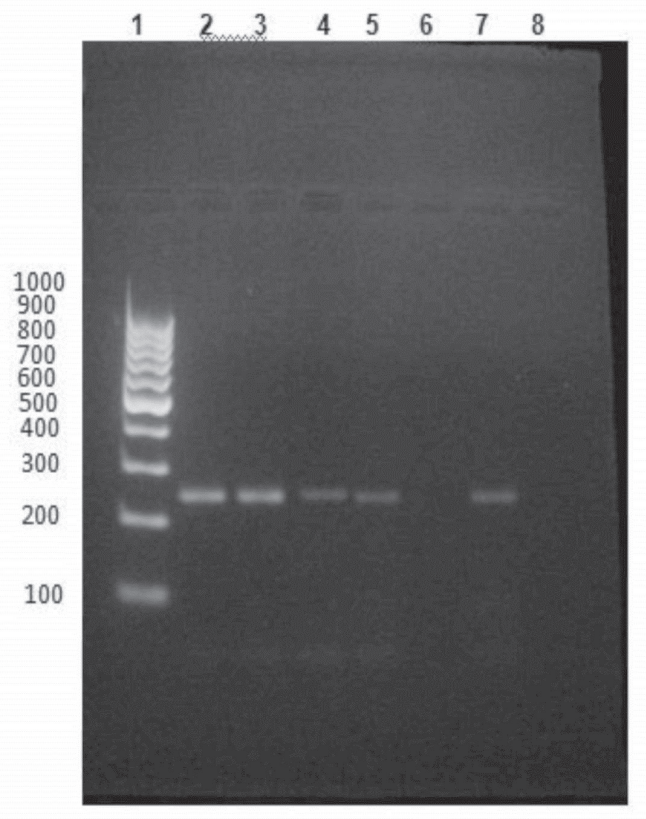

Fig. 1. The image of Brucella DNA which exists in 1.5\% of agarose gel, obtained from the PCR
Out of 54 milk samples collected from goats having a history of abortions, Funk et al., found that only 32 (59\%) of the samples tested positive using serology. However, 48 (88.8\%) of the samples were found to be positive with PCR. This number includes all 32 samples that tested positive with serology. After a single PCR, sensitivities of $2.2 \times 10^{6}$ and $2.8 \times 10^{7} \mathrm{CFU} / \mathrm{ml}$ were obtained for detection using agarose gel electrophoresis. In a controlled experiment, the sensitivity and specificity of this PCR was found to be $90 \%$ and $100 \%$, respectively. The specificity and high sensitivity of the PCR assay may provide a valuable tool for the diagnosis of brucellosis in goats (Funk et al., 2005). Hamdy and Amin (2002) conducted a study to examine milk samples using culture and PCR techniques to detect Brucella species. They isolated Brucella strains from milk samples of cattle (n.24), sheep (n.12) and goats (n.11) but did not isolate any Brucella strains from camel's milk.

Brucella was not isolated from the cheese and butter samples, which were investigated separately from the raw milk. Similar to some studies (Gulluce et al., 2003, Atas et al., 2007), we did not find any Brucella bacteria in the cheese and butter samples. On the other hand, several studies reported a wide range of percentages of positive values. For example, Atas et al. (2007) found a rate of 5.9\% in fresh and pickled cheese samples, Gulluce et al., (Gulluce et al., 2003) reported $21.66 \%$ in white cheese, civil cheese and lor cheese, (Alim and Tomul, 2005) identified a rate of

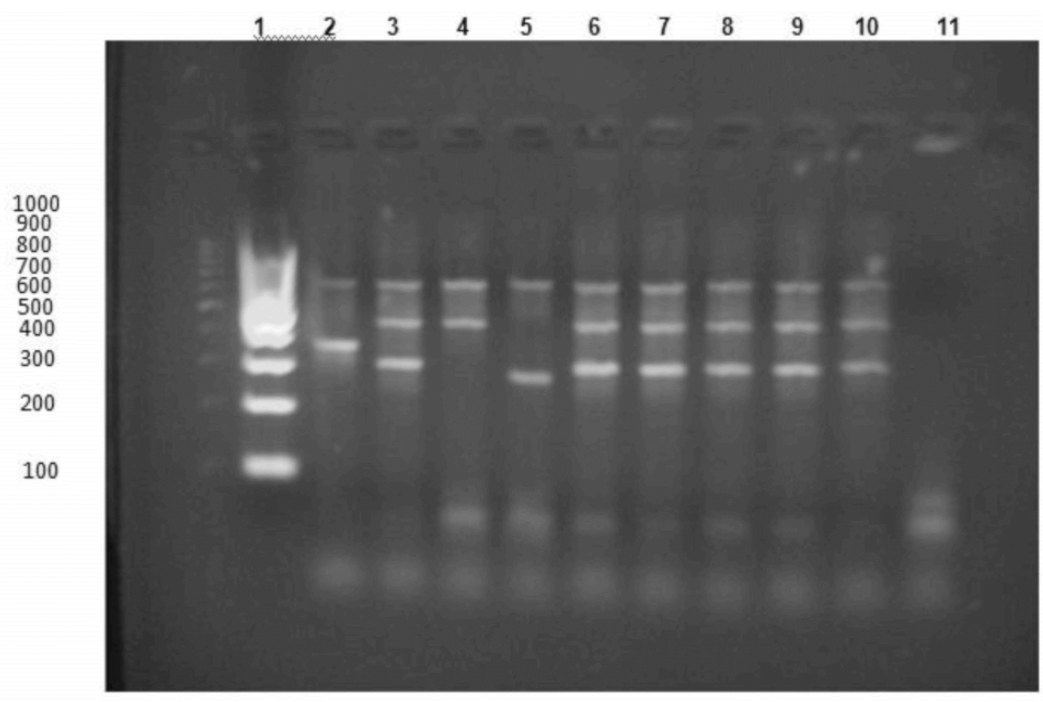

Fig. 2. The image of Brucella DNA which exists in 1.5\% of agarose gel, the determined on the basis of the species with help of applied Multiplex PCR kit. 
7.1-8.5\% in fresh cheese samples, and Barrow et al. (1968) reported a rate of $1.64 \%$ in cream and cream products.

There are a number of significant studies conducted on Brucellosis with different aims in the literature. For instance, Santiago-Rodriguez et al., studied the survival of the Brucella abortus aqpX mutant gene during the elaboration and conversion of fresh and ripened cheeses at and below room temperature (Santiago-Rodríguez et al., 2015). In another study, Ebrahimi et al. (2014) investigated the rate of $B$. melitensis seropositives and its probable shedding in lactating goat flocks in Iran's district zone. Mugizi et al.(2015) studied the epidemiology of Brucellosis by using phenotypic and molecular approaches to identify the Brucella species, biovars and genotypes occurring in cattle milk.

\section{CONCLUSION}

This study showed that milk samples pose a risk for B. abortus. The results of this research along with that of prior studies indicate that there has been a decrease in brucellosis infections thanks to positive results gained from increased efforts to fight brucellosis and reducing non-isolated Brucella agents in cheese and butter. Moreover, especially in recent years, the mentality of the producers has changed. They know that they need to heat or pasteurize raw milk before using it and this is a factor leading to the apparent decrease in the disease. Apart from these factors, in recent years large milk companies have been replacing family companies. Therefore, animal products have been produced in more hygienic conditions and from healthier animals. In addition, there has been an increase in programs that fight against contagious diseases. All of these factors can be considered to be reasons that the incidence rate of the brucellosis disease has decreased.

\section{REFERENCES}

1. Akpınar O (2016). Historical Perspective of brucellosis: a microbiological and epidemiological overview. Infez Med 1 24(1):77-86.

2. Ali S, Ali Q Melzer F, Khan I, Akhter S, Neubauer H, Jamal SM (2014). Isolation and Identification of Bovine Brucella Isolates from Pakistan by Biochemical Tests and PCR. Trop Anim Health Prod 46(1):73-78.

3. Alim A, Tomul ZD (2005). Investigation of Brucella in the fresh cheese samples sold at the bazaars of district in Sivas Center, Turkey. Mikrobiyol Bul 39:19-23.
4. Allmann M, Hofelein C, Koppel E, Luthy J, Meyer R, Niederhauser C, Wegmuller B, Candrian U (1995). Polymerase chain reaction (PCR) for detection of pathogenic microorganisms in bacteriological monitoring of dairy products. Res Microbiol 146:85-97.

5. Aparicio ED (2013). Epidemiology of brucellosis in domestic animals caused by B. melitensis, B. suis and B.abortus. Rev Sci Tech Off Int Epiz 32:53-60.

6. Arasoglu T, Gulluce M, Ozkan H, Adiguzel A, Sahin S (2013). PCR detection of B. abortus in cow milk samples collected from Erzurum, Turkey. Turk J Med Sci 43:501-508.

7. Atas M, Poyraz 0, Alim A, Atas AD, Celik A (2007). Investigation of Brucella in the fresh White Cheese and Brine for Pickling Cheeses sold in central of the Sivas. Turk Hij. Den Biyol Derg 64:9-14.

8. Atluri VL, Xavier MN, Jong MF, Hartigh AB, Tsolis RM (2011). Interactions of the human pathogenic Brucella species with their hosts. Annu Rev Microbiol 65:523-541.

9. Barrow GI, Path MC, Miller DC, Johnson DJ, Hingston CWJ (1968). Brucella abortus in fresh cream an cream product. British Med J 8:596-601.

10. Charisis NS (1998). The MZCP Report on the Third Workshop on Human and Animal Brucellozis Epidemiological Surveillance in the MZCP Countries. Damascus, Syrian Arab Republic.

11. Corbel MJ (1997). Brucellozis an Overview. $1^{\text {th }}$ International Conference on Emerging Zoonose. Emerging Infect Dis 3:213-221.

12. Celebi O, Celebi D, Balkan CE (2013). Effects of boiling dairy products on human Brucellosis. Eurasian J Med 45:73-76.

13. Celebi 0, Otlu S (2011). Bacteriological and molecular description of Brucella species isolated from milk and vaginal swab samples of aborted cattle in Kars region. Kafkas Univ Vet Fak Derg 17:53-58.

14. Cetinkaya Z, Aktepe OC, Ciftci IH, Demirel R (2005). Seroprevalence of human brucellosis in a rural area of Western Anatolia, Turkey. J Health Popul Nutr 23:137141.

15. Ebrahimi A, Milan JS, Mahzoonieh MR, Khaksar K (2014). Shedding rates and sero-prevalence of B. melitensis in lactating goats of Shahrekord, Iran. Jundishapur J Microbiol 7:93-94.

16. Farrell ID, Robertson L (1972). A comparison of various selective media, including a new selective medium for the isolation of Brucella from milk. J Appl Bacteriol 35:625630.

17. Funk ND, Tabatabai LB, Elzer PH, Hagius SD, Martin BM, Hoffman LJ (2005). Indirect Enzyme-Linked Immunosorbent Assay for detection of B. melitensis specific antibodies in goat milk. J Clin Microbiol 43:721725.

18. Garcell GH, Garcia G E, Pueyo V P, Martín R I, Arias VA, Serrano A RN (2016). Outbreaks of Brucellosis Related to the Consumption of Unpasteurized Camel Milk. J Infect Public Health 1876-0341(15)00241-5. doi: 10.1016/j. jiph.2015.12.006. 
19. Gulluce M, Adiguzel A, Algur OF (2003). Detection of Brucella antigens in different cheese in the Erzurum area by ELISA. Turk Mikrobiyol Cem Derg 33:356-360.

20. Gulluce M, Leloglu N (1996). Detection of B. abortus antibodies in cows milk of the Karsarea by ELISA and MRT. Turk J Vet Anim Sci 20:251-255.

21. Gupta VK, Verma DK, Rout PK, Singh SV, Vihan VS (2006). Polymerase chain reaction (PCR) for detection of $B$. melitensis in goat milk.

22. Hamdy MR, Amin AS (2002). Detection of Brucella species in the milk of infected cattle, sheep, goats and camels by PCR. The Vet 163:299-305.

23. Havas KAI, Boone RB, Hill AE, Salman MD (2014). A brucellosis disease control strategy for the Kakheti region of the country of Georgia an agent-based model. Zoonoses Public Health 61:260-270.

24. Herman L, Ridder HD (1992). Identification of Brucella spp. by using the polymerase chain reaction. Appl Environ Microbiol 58:2099-2101.

25. Iyisan AS, Akmaz O, Duzgun SG, Ersoy Y, Eskizmirliler E, Guler L, Gunduz K, Isik N, Icyerioglu AK, Kalender H, Karaman Z, Kucukayan U, Ozcan C, Seyitoglu S, Tuna I, Tunca T, Ustunakin K, Yurtalan S (2000). The Seroepidemiologic of brucellosis in ovine and cows in Turkey. Pendik Vet Mikrob Derg. 31:21-75.

26. Kara R, Akkaya L (2013). Investigation of B. abortus and B. melitensis at cheeses in Afyonkarahisar, Turkey. British J Dairy Scie 3:5-8.

27. Karagiannis I, Mellou K, Gkolfinopoulou K, Dougas G, Theocharopoulos G, Vourvidis D, Ellinas D, Sotolidou M, Papadimitriou T, Vorou R (2012). Outbreak investigation of brucellosis in Thassos, Greece, 2008. Euro Surveill 17: 201-206.

28. Kaynak-Onurdag F, Okten S, Sen B (2016) Screening Brucella spp. in Bovine Raw Milk by Real-time Quantitative PCR and Conventional Methods in a Pilot Region of Vaccination, Edirne, Turkey. J Dairy Sci S00220302(16)30061-3. doi: 10.3168/jds.2015-10637. [Epub ahead of print]

29. Lang R, Banai M, Lishner M, Rubinstein E (1995). Brucellozis. Int J Antimicrob Agents 5: 203-208.

30. Leal-Klevezas DS, Martínez-Vázquez IO, López-Merino A, Martínez-Soriano JP(1995). Single step PCR for detection of Brucella spp. from blood and milk of infected animals. J Clin Microbiol 33:3087-3090.

31. Leong KN, Chow TS, Wong PS, Hamzah SH, Ahmad N, Ch'ng CC.(2015). Outbreak of Human Brucellosis from Consumption of Raw Goats' Milk in Penang, Malaysia. Am J Trop Med Hyg 93(3):539-41. doi: 10.4269/ajtmh.15-0246.

32. Mailles A, Rautureau S, Le Horgne JM, Poignet-Leroux $B$, d'Arnoux C, Dennetière G, Faure M, Lavigne JP, Bru JP, Garin-Bastuji B (2012). Re-emergence of brucellosis in cattle in France and risk for human health. Euro Surveill $17: 202-207$
33. Mugizi DR, Muradrasoli S, Boqvist S, Erume J, Nasinyama GW, Waiswa C, Mboowa G, Klint M, Magnusson U (2015). Isolation and molecular characterization of Brucella isolates in cattle milk in Uganda. Biomed Res Int 2:1-9.

34. Pappas G, Papadimitriou P, Akritidis N, Christou L, Tsianos EV (2006). The new global map of human brucellosis. Lancet Infec Dis 6:91-99.

35. Qasem JA, AlMomin S, Al-Mouqati SA, Kumar V (2015). Characterization and Evaluation of an Arbitrary Primed Polymerase Chain Reaction (PCR) Product for the Specific Detection of Brucella Species. Saudi Journal Biological Sci 22(2):220-226.

36. Renukaradhya GJ, Isloor S, Rajasekhar M (2002), Epidemiology, zoonotic aspects, vaccination and control/ eradication of brucellozis in India. Vet Microbiol 90:183195.

37. Rock KT, Mugizi DR, Ståhl K, Magnusson U, Boqvist S (2016). The Milk Delivery Chain and Presence of Brucella Spp. Antibodies in Bulk Milk in Uganda. Trop Anim Health Prod. [Epub ahead of print]

38. Romero C, Pardo M, Grillo MJ, Diaz R, Blasco JM, Lopez-Goñi I (1995). Evaluation of PCR and indirect enzyme-linked immunosorbent assay on milk samples for diagnosis of brucellosis in dairy cattle. J Clin Microbiol 33:3198-3200.

39. Rudi K, Nogva HK, Moen B, Nissen H, Bredhold S, Møretrø T, Naterstad K, Holck A (2002). Development and application of new nucleic acid-based technologies for microbial community analyses in foods. Int J of Food Microb 78:171-180.

40. Santiago-Rodríguez MR, Díaz-Aparicio E, ArellanoReynoso B, García-Lobo JM, Gimeno M, PalomaresReséndiz EG, Hernández-Castro R (2015). Survival of Brucella abortus aqpX mutant in fresh and ripened cheeses. Foodborne Pathog Dis 12:170-175.

41. Shehu F, Biju B, Telo A, Mersini K, Koleci X, Abeshi J (2014). PCR method, used for detection of Brucella. spp in raw milk samples from Dibra Region-Albania. Wulfenia J 21:258-263.

42. Tantillo G, Pinto AD, Vergara A, Buonavoglia C (2001). Polymerase chain reaction for the direct detection of Brucella spp. in milk and cheese. J Food Protec 64:164167.

43. Turutoglu H, Mutluer B, Uysal Y (2003). Investigation of Brucella spp. in milk collected from Burdur province. Turk J Vet Anim Sci 27:1003-1009.

44. Wareth G, Melzer F, Elschner MC, Neubauer H, Roesler U (2014). Detection of B. melitensis in bovine milk and milk products from apparently healthy animals in Egypt by real-time PCR. J Infect Dev Ctries 8:1339-1343.

45. Yumuk Z, O'Callaghan D (2012). Brucellosis in Turkey an overview. Int J Infec Dis 16: 228-235.

46. Zowghi E, Ebadi A, Yarahmadi M (2008). Isolation and identification of Brucella organisms in Iran. Iranian. J Clin Infec Dis 3:185-188. 